THURSDAY, NOVEMBER 8, 1906.

\section{SCIENCE AND FOLLY.}

The Seven Follies of Science: a Popular Account of the most famous Scientific Impossibilities and the Attempts which have been Made to Solve Them. By John Phin. Pp. viii $+\mathrm{I} 78$. (London: Archibald Constable and Co., Ltd., Igo6.) Price 5s. net.

THESE "Follies" are the squaring of the circle, 1 the duplication of the cube, the trisection of an angle, perpetual motion, the transmutation of metals, the fixation of mercury, and the elixir of life; we miss from this list the flattening of the earth. The author is an American; he writes for ordinary readers, and makes his subject interesting; he seems to make no mistakes. He dwells at much greater length upon the first and fourth of the follies than the rest. In addition to these seven classical ones he gives an account of four others : perpetual lamps, the alkahest or universal solvent, palingenesy (the revival of a plant or animal from its ashes), and the powder of sympathy. He adds a division on the fourth dimension of space and some paradoxes, micrography, illusions of the senses, and two tricks. The book finishes with an account of some arithmetical problems and the fulcrum of Archimedes which are probably " curious" to the ordinary reader.

Readers of Nature, and not merely ordinary readers, may spend a pleasant hour or two in looking through this book, reflecting on the follies, not of scientific persons, but of those persons supposed to be cultured who are ignorant of physical science in an age when applications of the principles of physical science are transforming the world, Our greatest legislators and writers and divines are no better guarded mentally from tricksters than their ancestors. We know that a new Mahomet might have just as much success with cultured and uncultured persons in the twentieth as in the seventh century, but it is startling to find that a new Cagliostro might probably be even more successful in the twentieth than in the eighteenth century. A scientific man does not deny the possibility of almost any miracle, he only says that it is extremely improbable. He admits that man is probably limited in his senses and faculties, and that all his physical laws are mere analogies; that real comprehension of the universe is altogether out of the question. These admissions have become known now to unscientific persons, and no Swedenborgian was more ready to take the cock-and-bull statements of his master on trust than 99 per cent. of newspaper readers and writers at the present time are willing to accept absurd stories as true. A cultured person says that of course a perpetual motion is impossible, but he invests his money in a company which promotes something which is really meant to create energy. He scorns the Middle Age idea that a sympathetic powder applied to a dagger will cure a distant wounded person, but although he has been to a public school he is a profound believer in Christian science.

NO. I932, VOL. 75]
Few men probably receive more communications from earth flatteners and circle squarers and arc trisectors than the present writer. When he receives one he does not feel pleased, and yet it ought to be pleasant to think that there are so many men in the world who refuse to accept dogma. A crank is defined as a man who cannot be turned. These men are all cranks; at all events, we have never succeeded in convincing one of them that he was wrong. The usually accepted axioms, definitions, and technical terms are not for them. When they use a term, sometimes evidently in two different senses in the same syllogism, it is impossible to find exactly what they mean by it. If Mr. Phin had had his reviewer's experience, he would have greatly added to the size of his book by referring to many parts of physics where men are just as unwilling now to accept authority as the men of whom he writes; and he would have pointed out that our real difficulty is with the men who are partly right, men who think they have a new idea and try to explain it in unscientific language, and, as they do so, denounce the orthodox beliefs which they have been unable to understand.

From many follies the common people have been saved for ever by the engineers, the men who apply science. In this twentieth century it is difficult to believe in sympathetic wax images and powders and the other things cherished by our ancestors who executed witches, because miraculous railway trains and telegraphs and telephones and thousands of things to be seen in every shop, on every street, on every road are known to be explainable in reasonable ways. To believe now in the evil eye or devil possession, ghosts, haunted houses, or the powers of the esoteric Buddhist it is necessary to have a very special kind of mental power and of education and environment. It may be that only one in every 100,000 of the inhabitants of these islands is capable of snatching the fearful joy which accompanies such beliefs.

As already said, we think that the author of this book makes no mistakes, but if he had known more he might have made the book a much larger one with advantage, and we cannot help thinking that he is not well read in the delightful memoirs of the sixteenth century, when witchcraft had a really good time. Then, as to a fourth or twentieth dimension in space, he gives practically no information to the expectant reader in this division of his work, yet there is probably no subject on which the cultured reader of the present day desires instruction more (perhaps excepting radium). A man may get some knowledge of Greek or Japanese literature without knowing the Greek or Japanese languages, and so the cultivated person hopes to get scientific ideas without knowing the language of science. The author hardly tries to hide his own ignorance of this part of his subject, and here, as everywhere else, he gives only what he him. self feels sure that he understands. He writes for the man in the street, and we can give no higher praise than to say that the man in the street will understand him.

J. P. 